\section{Cureus}

Received 10/07/2015

Review began 10/10/2015

Review ended 01/07/2016

Published 02/02/2016

C) Copyright 2016

Leveson et al. This is an open access article distributed under the terms of the Creative Commons Attribution License CC-BY 3.0., which permits unrestricted use, distribution, and reproduction in any medium, provided the original author and source are credited.

\title{
Radiotherapy for Langerhans Cell Histiocytosis of Bilateral Eyelids
}

\author{
James Leveson $^{1}$, Jean-Marc Bourque ${ }^{2}$, Jelena Lukovic ${ }^{2}$, A. Rashid Dar ${ }^{3}$ \\ 1. King's College London 2. Department of Radiation Oncology, London Regional Cancer Program 3. \\ Department of Radiation Oncology, London Regional Cancer Program, Western University
}

$\square$ Corresponding author: James Leveson, james.leveson@gmail.com

Disclosures can be found in Additional Information at the end of the article

\section{Abstract}

Langerhans cell histiocytosis (LCH) is a rare disorder with numerous clinicopathological variants with differing clinical courses, treatment methods, and prognoses. We report one patient with atypical LCH of the bilateral lower eyelids and subsequent successful treatment with local radiation therapy.

Categories: Ophthalmology, Radiation Oncology

Keywords: ophthalmology, local, radiation therapy, lch, histiocytosis $\mathrm{x}$, langerhans cell histiocytosis

\section{Introduction}

Langerhans cell histiocytosis ( $\mathrm{LCH})$ is uncommon in the general population, and there is a paucity of literature on this topic. The disease can present in various forms and local treatment varies widely depending on the affected site. We present a case of atypical LCH in which numerous initial local treatments were unsuccessful. Finally, we demonstrate the effectiveness of radiotherapy as a treatment of $\mathrm{LCH}$, significantly improving the patient's quality of life.

\section{Case Presentation}

Informed patient consent was obtained for this patient's treatment.

In November 2007, a 37-year-old white male presented to his family physician complaining of bilateral lower eyelid growths that had progressed from the left to the right side. He was initially diagnosed as chalazion with blepharitis and treated with local steroid injection without improvement. In July 2008, a skin biopsy specimen of the left lower lid (tarsal conjunctival area) showed high cellularity, Langerhans cells (LCs) with nuclear grooves and intranuclear inclusions, numerous eosinophils, lymphocytes, macrophages, neutrophils, and giant cells. There was no extra-orbital disease; orbital CT revealed no gross abnormalities and MRI of the head showed the craniocervical anatomy to be normal. Bone marrow aspiration revealed normal cellular trilineage hematopoietic marrow. Further investigations, including chest x-ray and routine blood work, revealed no other abnormalities. Review of the patient presentation and histology supported the diagnosis of LCH.

Once this diagnosis was confirmed, the patient underwent surgical debulking with subsequent periodic corticosteroid injections. This therapy did not achieve adequate control, and the disease subsequently progressed, with an invasion of the cilia bilaterally and the right tarsus muscle (Figure 1). No visual disturbances were found. 


\section{Cureus}

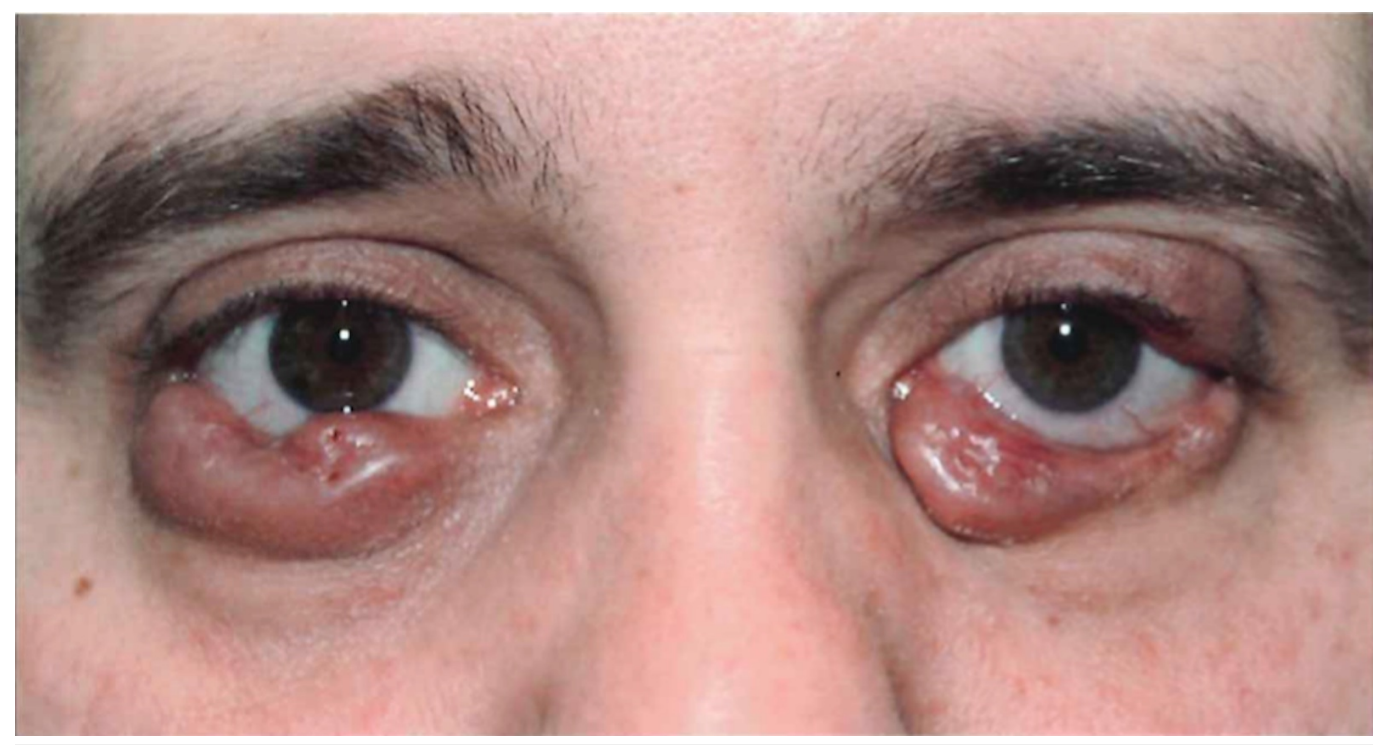

FIGURE 1: Before radiation treatment (February 2012)

Prior treatments included surgical debulking and periodic steroid injections.

In February 2012, the patient was treated with a dose of 2,100 cGy in seven fractions utilizing 6 $\mathrm{MeV}$ electrons with a $0.5 \mathrm{~cm}$ bolus over the skin on each eyelid. The patient tolerated the therapy well with madarosis and exophthalmia being his main complications, for which he used TobraDex drops. At his three month follow-up by the radiation oncology, ophthalmology, and plastic surgery teams, the patient was noted to have a near-complete response with a remarkable cosmetic outcome. There was some residual whitish area on the left outer superior margin of the eyelid, corresponding to necrosis, but no evidence of residual disease (Figure 2). His vision was 20/25 bilaterally and the corneas were unremarkable. Unfortunately, no further follow-up information is available due to non-attendance.

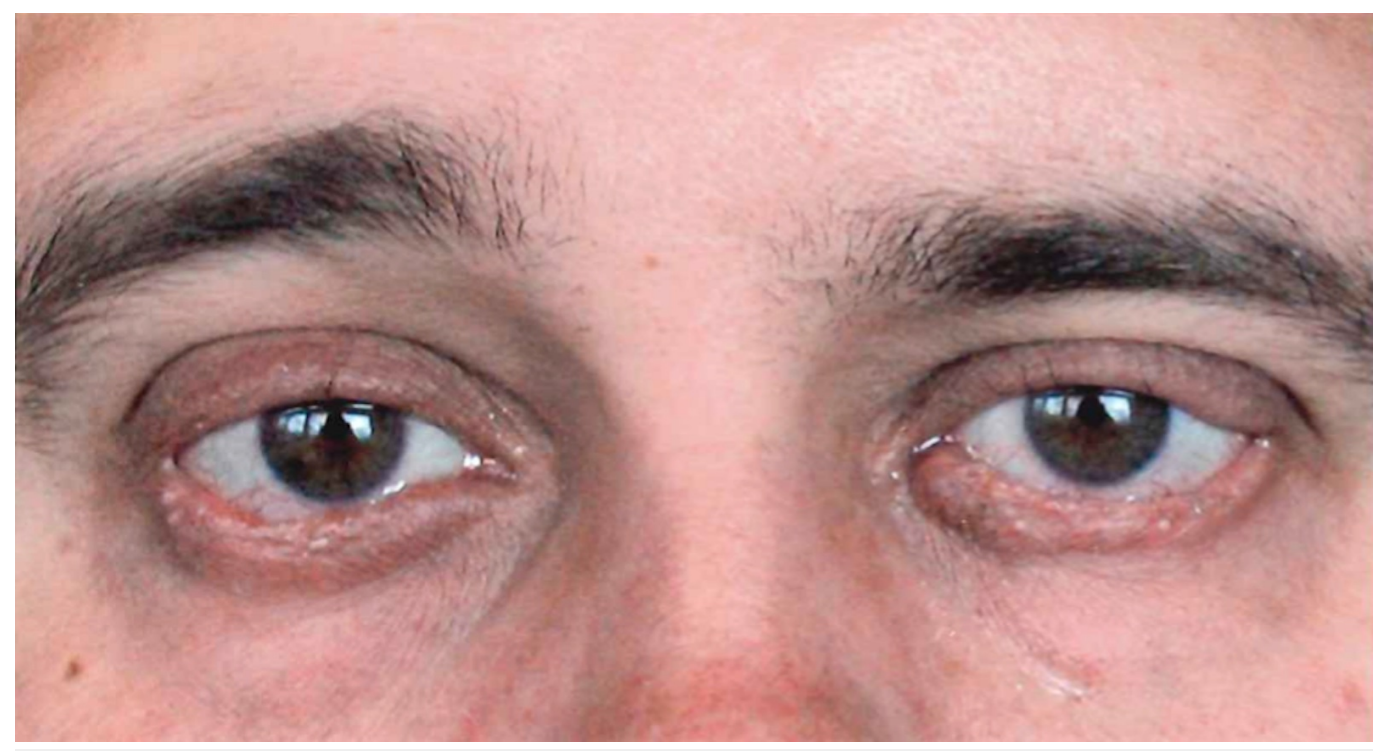

FIGURE 2: After radiation treatment (April 2012)

$7 \times 300$ cGy exposure $=2100$ cGy total exposure. 


\section{Discussion}

Histiocytes are cells belonging to the reticuloendothelial system and include monocytes/macrophages, dermal/interstitial dendritic cells, and Langerhans cells (LC). They are hypothesised to arise from a common CD-34 positive progenitor cell within the bone marrow, which further differentiates along two major pathways, namely, CD-14 positive cells or CD-14 negative cells. CD-14 positive cells differentiate into macrophages and dendritic cells, and CD-14 negative cells become LCs. LCs are usually characterised by the presence of Birbeck granules, which are organelles thought to be involved in antigen internalisation [1-2].

The histiocytoses encompass a heterogeneous group of proliferative disorders distinguished by the accumulation of histiocytes and other immune effector cells within various tissues.

Currently, they are classified into three classes based on the predominant cell type present [3].

LCH, a Class I histiocytosis, is a rare disease with an estimated incidence of 4.0-5.4 cases per million children per year [4]. It affects patients from the neonatal period through to adulthood, although it appears to be more common amongst children. Robust epidemiological data is difficult to attain in the literature due to the rarity of the disease; however, it has been observed that it is more common among whites. So far, there has been minimal progress in assessing the cause of LCH but some associations with thyroid disease have been demonstrated.

The pathophysiology of LCH remains elusive [5]. Research understanding of LCH has been greatly improved by analysing primary human material with advanced genomic technologies. LCH may arise from an earlier precursor cell given that cell gene expression is different from those in normal Langerhans cells (LCs), although this is not incongruous with the hypothesis that LCs are the cell of origin. Langerhans cells have been demonstrated to be clonal, and recent advances have identified activating BRAF mutations, which strongly suggests LCH is a neoplastic disease. However, the frequently benign course of the disease and a prominent inflammatory component suggest that LCH may not be a neoplasm.

LCH has a wide range of clinicopathological presentations [6]. It may involve almost any organ system, but the frequency and extent of disease are often age-dependent. In neonates and children under four years, it most frequently presents as a multiorgan disease (51\% to 71\%) [711]. Most retrospective studies in adults show that adults only have involvement of a single organ system (69\% to $72 \%$ ) [7-15]. However, a recent large multinational retrospective study contradicts these reports, attributing the higher observed systemic disease (68.9\%) to improved recognition and diagnosis [15]. When a single organ system is involved, LCH is most often characterised by bone lesions (52\%), lung lesions (40\%), or skin lesions (7\%), but central nervous system involvement has also been described.

Diagnosing LCH involves identification of the characteristic clinical features as well as a corroboration of the histological (uncontrolled clonal proliferation of normal human mononuclear phagocytes called Langerhans cells) and immunohistochemical results (lesional cells staining positive for S-100 and CD1a) [16-17]. Other pathognomonic markers are being sought. Investigations often include full skeletal radiographic survey and chest radiography but more specific investigations, such as bone marrow evaluation, may be required. In our patient, the similarity of the presentation to more common ophthalmological disease initially led to misdiagnosis and a delay in treatment.

Treatment protocol for LCH depends on a number of variables [3, 18-19]. Treatment of multisystem disease is based on the LCH-III protocol [20]. However, this discussion will explore treatment options for the single system (cutaneous) disease. Whilst patients with the limited 
cutaneous disease usually require no therapy, steroids are often utilised. Topical nitrogen mustard or psoralen combined with ultraviolet A (PUVA) treatment are viable second-line options [21].

Radiation therapy (RT) is considered an appropriate option for LCH, particularly when local control is challenging in recurrent and progressive lesions [22]. In a recent retrospective study with 80 patients, RT was shown to be an extremely well-tolerated option, with even low RT doses demonstrating sufficient control. In this study, RT was carried out with a median cumulative dose of $15 \mathrm{~Gy}$ (range: 3 - $50.4 \mathrm{~Gy}$ ) and a median $2 \mathrm{~Gy}$ dose per fraction (range: 1.8 - 3 Gy). Additionally, radiogenic side and late effects ₹ EORTC/RTOG Grade 2 were not observed, and there were no treatment-related deaths or secondary malignancies reported after a median follow-up of 54 months (range: 9 - 134 months) [23].

Other studies also support the efficacy of RT in the treatment of LCH [24-28]. One study with twenty-two LCH patients, where 56 sites of LCH were irradiated (40 bone, 16 soft tissue), achieved local control in $82 \%$ of these sites utilising a median dose of $900 \mathrm{cGy}$ for bone (range: $600-1,500$ ) and 1,500 cGy for soft tissue sites (range: $600-2,600$ ). Another particular case report describing a paediatric orbital manifestation of LCH also achieved remission following external radiotherapy (1,500 cGy total dose in three fractions) [29].

\section{Conclusions}

$\mathrm{LCH}$ is a rare disease with multiple clinicopathological variants. Treatment regime varies depending on multiple factors. We have described a case where the use of localised RT successfully achieved a complete response with a remarkable cosmetic outcome. This adds to the evidence supporting RT as an effective, safe, and simple treatment option in recurrent and progressive lesions.

\section{Additional Information}

\section{Disclosures}

Human subjects: Consent was obtained by all participants in this study. Conflicts of interest: In compliance with the ICMJE uniform disclosure form, all authors declare the following: Payment/services info: All authors have declared that no financial support was received from any organization for the submitted work. Financial relationships: All authors have declared that they have no financial relationships at present or within the previous three years with any organizations that might have an interest in the submitted work. Other relationships: All authors have declared that there are no other relationships or activities that could appear to have influenced the submitted work.

\section{References}

1. Hanau D, Gothelf Y, Schmitt DA, Fabre M, Garaud JC, Gazit E, Cazenave JP: Internalization by receptor-mediated endocytosis of T6 (CD1 "NA1/34") surface antigen in T6 positive human cord blood cells (Langerhans cell precursors?). Nouv Rev Fr Hematol. 1987, 29:279-83.

2. Weitzman S, Jaffe R: Uncommon histiocytic disorders: The non-Langerhans cell histiocytoses . Pediatr Blood Cancer. 2005, 45:256-64. 10.1002/pbc.20246

3. Harris NL, Jaffe ES, Diebold J, Flandrin G, Muller-Hermelink HK, Vardiman J, Lister TA, Bloomfield CD: The World Health Organization classification of neoplastic diseases of the hematopoietic and lymphoid tissues. Report of the Clinical Advisory Committee meeting, Airlie House, Virginia, November, 1997. J Clin Oncol. 1999, 17:3835-49.

4. Nicholson HS, Egeler RM, Nesbit ME: The epidemiology of Langerhans cell histiocytosis . Hematol Oncol Clin North Am. 1998, 12:379-84. 10.1016/S0889-8588(05)70517-7

5. Badalian-Very G, Vergilio JA, Fleming M, Rollins BJ: Pathogenesis of Langerhans cell 
histiocytosis. Annu Rev Pathol. 2013, 8:1-20. 10.1146/annurev-pathol-020712-163959

6. Satter EK, High WA: Langerhans cell histiocytosis: a review of the current recommendations of the Histiocyte Society. Pediatr Dermatol. 2008, 25:291-95. 10.1111/j.1525-

1470.2008.00669.x

7. Donaldieu J, Thomas C, Brugieres L, Herbelin C, Bertrand Y, Schmitt C, Robert A, Fragnou C, Emile JF, Micheau M, Gentet JC, Plantaz D, Teillac-Hamel D, Edan C, Demeocq F, Mechinaud F, Leverger G: A multicentre retrospective survey of Langerhans' cell histiocytosis: 348 cases observed between 1983 and 1993. The French Langerhans' Cell Histiocytosis Study Group. Arch Dis Child. 1996, 75:17-24. 10.1136/adc.75.1.17

8. Stein SL, Paller AS, Haut PR, Mancini AJ: Langerhans cell histiocytosis presenting in the neonatal period: a retrospective case series. Arch Pediatr Adolesc Med. 2001, 155:778-83. 10.1001/archpedi.155.7.778

9. Longaker MA, Frieden IJ, LeBoit PE, Sherertz EF: Congenital "self-healing" Langerhans cell histiocytosis: the need for long-term follow-up. J Am Acad Dermatol. 1994, 31:910-16.

10.1016/S0190-9622(94)70258-6

10. Bhatia S, Nesbit ME Jr, Egeler RM, Buckley JD, Mertens A, Robison LL: Epidemiologic study of Langerhans cell histiocytosis in children. J Pediatr. 1997, 130:774-84. 10.1016/S00223476(97)80021-2

11. Isaacs H: Fetal and neonatal histiocytoses. Pediatr Blood Cancer. 2006, 47:123-29. 10.1002/pbc.20725

12. Alston RD, Tatevossian RG, McNally RJ, Kelsey A, Birch JM, Eden TO: Incidence and survival of childhood Langerhans cell histiocytosis in Northwest England from 1954 to 1998. Pediatr Blood Cancer. 2007, 48:555-60. 10.1002/pbc.20884

13. Howarth DM, Gilchrist GS, Mullan BP, Wiseman GA, Edmonson JH, Schomberg PJ: Langerhans cell histiocytosis: diagnosis, natural history, management, and outcome. Cancer. 1999, 85:2278-90. 10.1002/(SICI)1097-0142(19990515)85:10<2278::AID-CNCR25>3.0.CO;2-U

14. Götz G, Fichter J: Langerhans'-cell histiocytosis in 58 adults . Eur J Med Res. 2004, 9:510-14.

15. Aricò M, Girschikofsky M, Généreau T, Klersy C, McClain K, Grois N, Emile JF, Lukina E, De Juli E, Danesino C: Langerhans cell histiocytosis in adults. Report from the International Registry of the Histiocyte Society. Eur J Cancer. 2003, 39:2341-48. 10.1016/S09598049(03)00672-5

16. Chu T, D'Angio GJ, Favara BE, Ladisch S, Nesbit M, Pritchard J: Histiocytosis syndromes in children. Writing Group of the Histiocyte Society. Lancet. 1987, 1:208-9. 10.1016/S01406736(87)90016-X

17. Broadbent V, Gadner H, Komp DM, Ladisch S: Histiocytosis syndromes in children: II. Approach to the clinical and laboratory evaluation of children with Langerhans cell histiocytosis. Clinical Writing Group of the Histiocyte Society. Med Pediatr Oncol. 1989, 17:492-95. 10.1002/mpo.2950170527

18. Hicks J, Flaitz CM: Langerhans cell histiocytosis: current insights in a molecular age with emphasis on clinical oral and maxillofacial pathology practice. Oral Surg Oral Med Oral Pathol Oral Radiol Endod. 2005, 100:S42-66. 10.1016/j.tripleo.2005.06.016

19. Arceci RJ, Brenner MK, Pritchard J: Controversies and new approaches to treatment of Langerhans cell histiocytosis. Hematol Oncol Clin North Am. 1998, 12:339-57.

10.1016/S0889-8588(05)70514-1

20. Langerhans Cell Histiocytosis: Evaluation and Treatment Guidelines . (2009). Accessed: July 2015: https://www.histiocytesociety.org/document.doc?id=290.

21. Munn S, Chu AC: Langerhans cell histiocytosis of the skin. Hematol Oncol Clin North Am. 1998, 12:269-86. 10.1016/S0889-8588(05)70510-4

22. Kriz J, Eich HT, Bruns F, Heyd R, Schäfer U, Haverkamp U, Büntzel J, Seegenschmiedt H, Micke $\mathrm{O}$ : Radiotherapy in langerhans cell histiocytosis - a rare indication in a rare disease . Radiat Oncol. 2013, 8:233. 10.1186/1748-717X-8-233

23. Cox JD, Stetz J, Pajak TF: Toxicity criteria of the Radiation Therapy Oncology Group (RTOG) and the European Organization for Research and Treatment of Cancer (EORTC). Int J Radiat Oncol Biol Phys. 1995, 31:1341-46. 10.1016/0360-3016(95)00060-C

24. Selch MT, Parker RG: Radiation therapy in the management of Langerhans cell histiocytosis . Med Pediatr Oncol. 1990, 18:97-102. 10.1002/mpo.2950180203

25. Gramatovici R, D'Angio GJ: Radiation therapy in soft-tissue lesions in histiocytosis X (Langerhans' cell histiocytosis). Med Pediatr Oncol. 1988, 16:259-62. 


\section{Cureus}

\subsection{2/mpo.2950160407}

26. Heyd R, Strassmann G, Donnerstag F, Martin T, Zamboglou N: Radiotherapy in Langerhanscell histiocytosis. 2 case reports and review of the literature (Article in German). Rontgenpraxis. 2000, 53:51-61.

27. Kotecha R, Venkatramani R, Jubran RF, Arkader A, Olch AJ, Wong K: Clinical outcomes of radiation therapy in the management of Langerhans cell histiocytosis. Am J Clin Oncol. 2014, 37:592-96. 10.1097/COC.0b013e318281d6ce

28. Olschewski T, Seegenschmiedt MH: Radiotherapy of Langerhans' cell histiocytosis: Results and implications of a national patterns-of-care study. Strahlenther Onkol. 2006, 182:629-34. 10.1007/s00066-006-1630-9

29. Das JK, Soibam R, Tiwary BK, Magdalene D, Paul SB, Bhuyan C: Orbital manifestations of Langerhans cell histiocytosis: A report of three cases. Oman J Ophthalmol. 2009, 2:137-40. 10.4103/0974-620X.57315 